In cooperation with the Louisiana Department of Transportation and Development

\title{
Water Resources of Bossier Parish
}

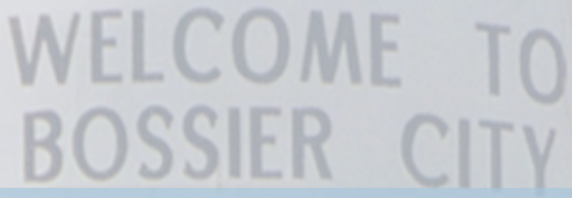

\section{Introduction}

In 2005, about 15.8 million gallons per day (Mgal/d) of water were withdrawn in Bossier Parish, Louisiana (fig. 1), including 4.12 Mgal/d from groundwater sources and about $11.7 \mathrm{Mgal} / \mathrm{d}$ from surface-water sources ${ }^{1}$ (table 1). Publicsupply use accounted for about 78 percent $(12.4 \mathrm{Mgal} / \mathrm{d})$ of the total water withdrawn. Other categories of use included

\footnotetext{
${ }^{1}$ Tabulation of numbers in text and tables may result in different totals because of rounding; nonrounded numbers are used for calculation of totals.
}

industry, rural domestic, livestock, rice irrigation, general irrigation, and aquaculture (table 2). Based on water-use data collected at 5-year intervals from 1960 to 2005, water withdrawals in the parish increased from 4.96 to $15.8 \mathrm{Mgal} / \mathrm{d}$ (fig. 2).

This fact sheet summarizes basic information on the water resources of Bossier Parish, La. Information on groundwater and surface-water availability, quality, development, use, and trends is based on previously published reports listed in the Selected References section.
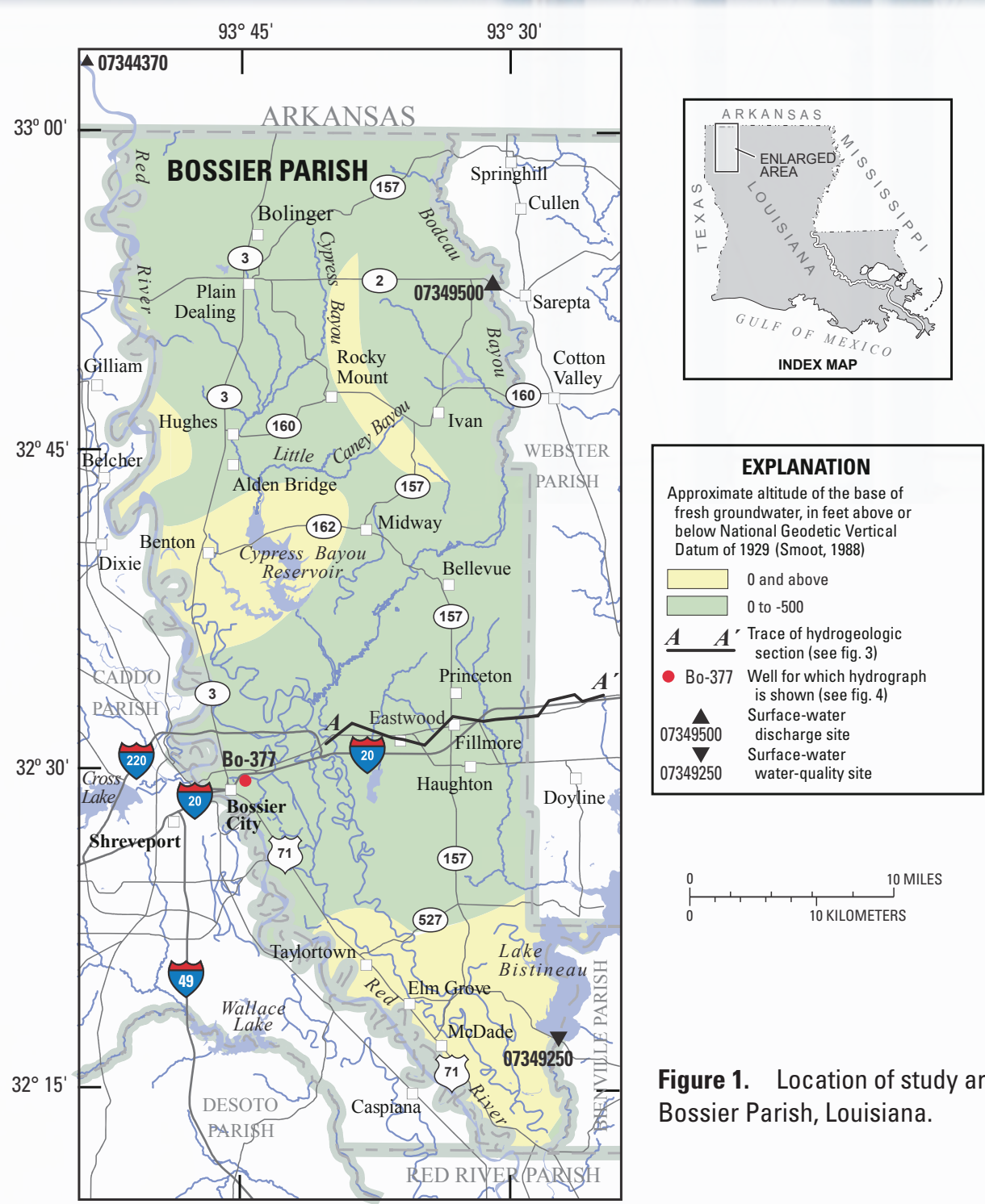

Figure 1. Location of study area, Bossier Parish, Louisiana. 
Table 1. Water withdrawals, in million gallons per day, by source in Bossier Parish, Louisiana, 2005 (modified from Sargent, 2007).

\begin{tabular}{lcc}
\hline \multicolumn{1}{c}{$\begin{array}{c}\text { Aquifer or surface- } \\
\text { water body }\end{array}$} & Groundwater & Surface water \\
\hline Red River alluvial aquifer & 0.49 & - \\
Upland terrace aquifer & .99 & - \\
Sparta aquifer & .19 & - \\
Carrizo-Wilcox aquifer & 2.45 & - \\
Red River & - & 10.67 \\
Miscellaneous streams & - & 11.08 \\
Total & 4.12 & \\
\hline
\end{tabular}

Table 2. Water withdrawals, in million gallons per day, by category in Bossier Parish, Louisiana, 2005 (modified from Sargent, 2007).

\begin{tabular}{lccr}
\hline \multicolumn{1}{c}{ Category } & Groundwater & $\begin{array}{c}\text { Surface } \\
\text { water }\end{array}$ & Total \\
\hline Public supply & 1.73 & 10.67 & 12.40 \\
Industrial & .42 & .02 & .44 \\
Rural domestic & 1.28 & .00 & 1.28 \\
Livestock & .07 & .02 & .09 \\
Rice irrigation & .16 & .00 & .16 \\
General irrigation & .24 & .97 & 1.22 \\
Aquaculture & .21 & .00 & .21 \\
\cline { 2 - 4 } Total & 4.12 & 11.68 & 15.80 \\
\hline
\end{tabular}

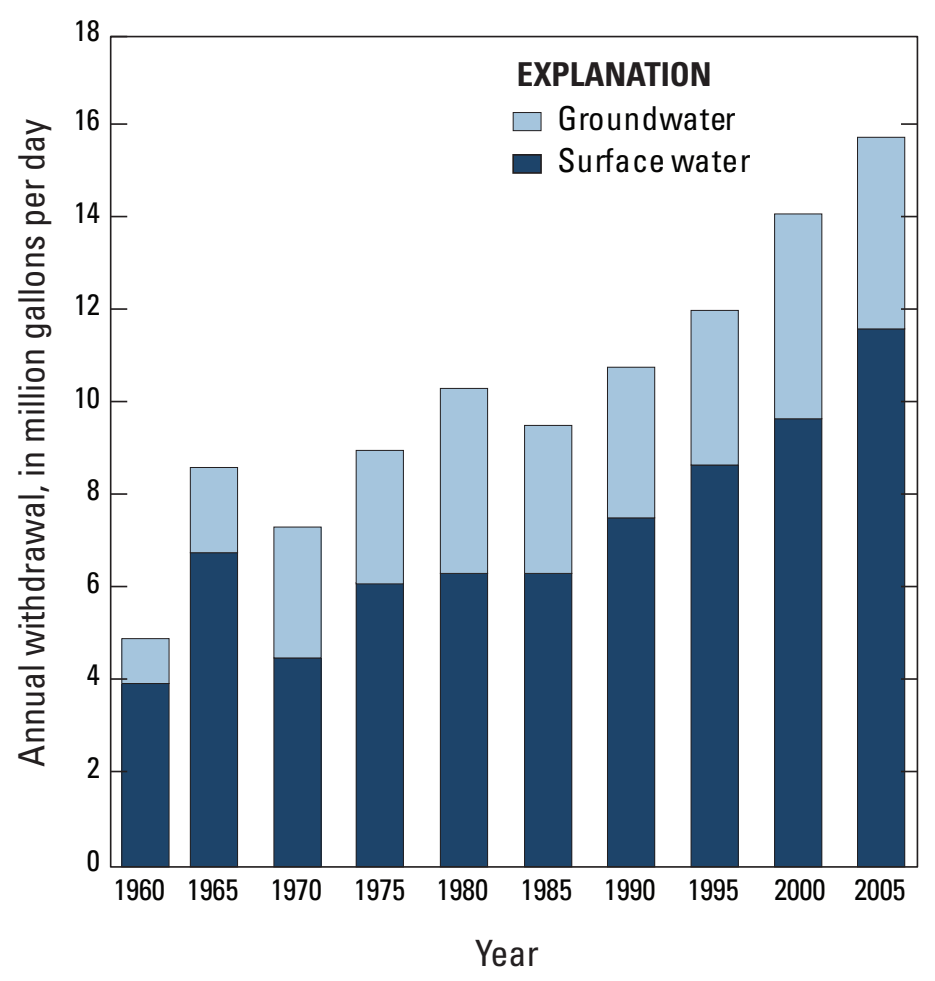

Figure 2. Water withdrawals in Bossier Parish, Louisiana, 1960-2005.

\section{Groundwater Resources}

The primary groundwater resources of Bossier Parish, from near surface to deepest, include the Red River alluvial aquifer, the upland terrace aquifer, the Sparta aquifer, and the CarrizoWilcox aquifer (fig. 3). Fresh groundwater (water having a chloride concentration of 250 milligrams per liter [mg/L] or less) is available throughout most of the parish at depths ranging from about 50 feet (ft) above the National Geodetic Vertical Datum of 1929 (NGVD 29) (sea level) near the southern parish line to about $400 \mathrm{ft}$ below NGVD 29 near the northern parish line (fig. 1). Recharge to aquifers in Bossier Parish is from precipitation, leakage from adjacent aquifers, and seasonal input from streams. Discharge from the aquifers is by natural seasonal flow into streams, leakage into adjacent aquifers, and withdrawals from wells.

State well-registration records listed 3,236 active water wells in Bossier Parish in 2009, including 2,942 domestic, 144 public-supply, 104 irrigation, and 46 industrial wells. In 2005, groundwater withdrawals for various uses included public supply, industry, rural domestic, livestock, rice irrigation, general irrigation, and aquaculture (table 2).

\section{Red River Alluvial Aquifer}

In Bossier Parish, the Red River alluvial aquifer extends about 5 to 7 miles (mi) east of the Red River (fig. 1) except between the town of Benton and State Highway 2, where the aquifer extends less than a mile east of the river. Alluvial deposits in the Red River flood plain characteristically have a uniform sequence of clay, silt, sand, and gravel, with grain size increasing with depth. Sand and gravel deposits compose the Red River alluvial aquifer. The aquifer is partially confined in some areas by highly organic backswamp clay deposits having low permeability, thus restricting infiltration of precipitation. In Bossier Parish, the alluvial aquifer ranges in thickness from about 15 to $80 \mathrm{ft}$ and is overlain by about 10 to $60 \mathrm{ft}$ of surficial clay and silt.

Water levels in the alluvial aquifer fluctuate primarily in response to the stage of the Red River and precipitation. The hydrograph for well Bo-337 illustrates water-level fluctuations (fig. 4). Groundwater flow in the aquifer is towards the Red River, with a general southerly (down valley) component of flow. Recharge to the alluvial aquifer is from precipitation that infiltrates the overlying silty soil and from adjacent aquifers.

State well-registration records listed 94 active water wells screened in the Red River alluvial aquifer in Bossier Parish in 2009, including 52 irrigation, 34 domestic, 5 industrial, and 3 public-supply wells. Depths of these wells ranged from 30 to $110 \mathrm{ft}$ below land surface, with a median depth of $70 \mathrm{ft}$. Yields from wells screened in the Red River alluvial aquifer in Bossier Parish have reportedly ranged from 1 to 1,000 gallons per minute (gal/min). In 2005, withdrawals from the Red River alluvial aquifer in Bossier Parish totaled about $0.49 \mathrm{Mgal} / \mathrm{d}$ (table 1) and included about $0.02 \mathrm{Mgal} / \mathrm{d}$ for ruraldomestic use, $0.04 \mathrm{Mgal} / \mathrm{d}$ for livestock, $0.09 \mathrm{Mgal} / \mathrm{d}$ for rice irrigation, $0.13 \mathrm{Mgal} / \mathrm{d}$ for general irrigation, and $0.21 \mathrm{Mgal} / \mathrm{d}$ for aquaculture. Water in the Red River alluvial aquifer is generally very hard (greater than $180 \mathrm{mg} / \mathrm{L}$ as calcium carbonate) and has high iron concentrations (greater than $300 \mu \mathrm{g} / \mathrm{L}$ ). 


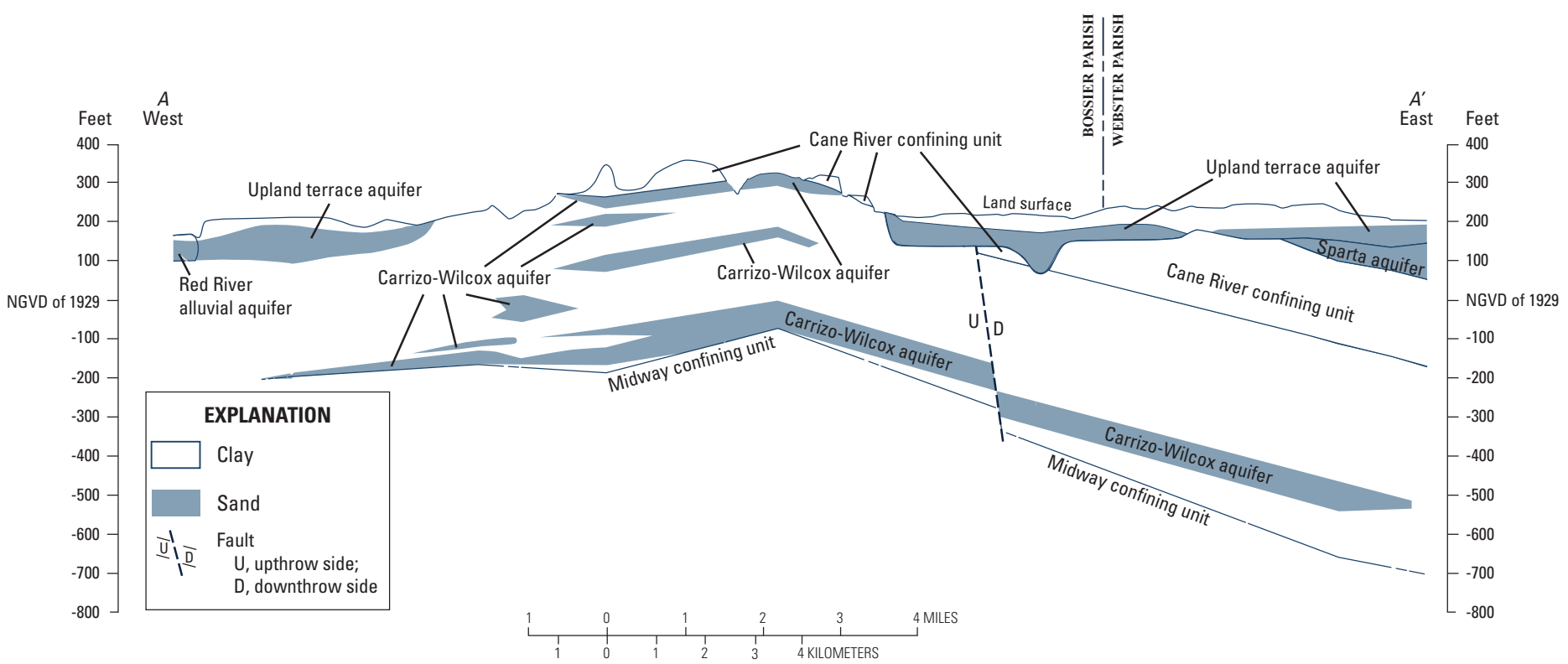

Figure 3. Generalized west-to-east hydrogeologic section from western Bossier Parish to eastern Webster Parish, Louisiana (modified from Snider, 1983). Trace of section shown on figure 1.

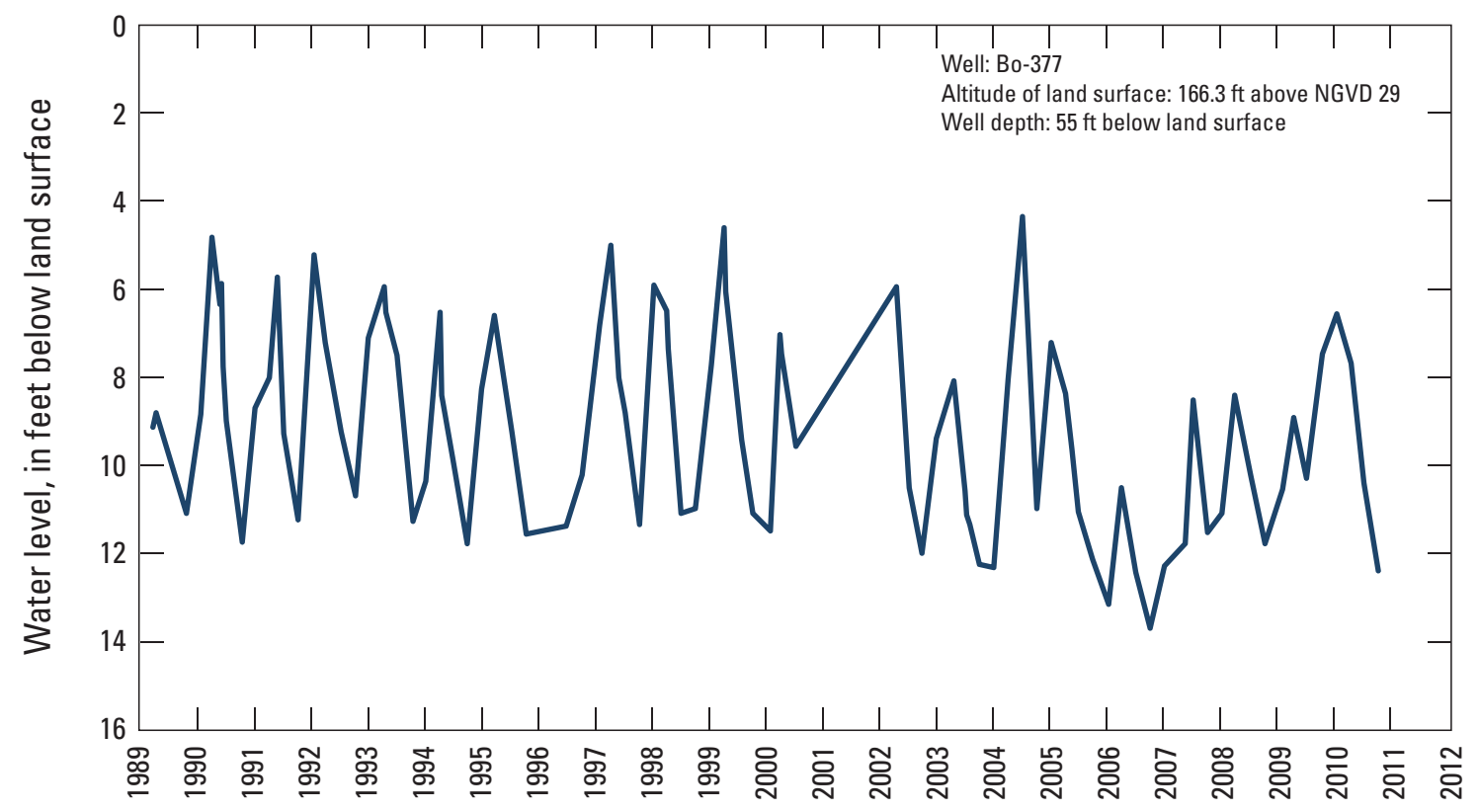

Figure 4. Water levels in well Bo-377 screened in the Red River alluvial aquifer in Bossier Parish, Louisiana (see fig. 1 for well location; U.S. Geological Survey, 2010a). Land surface is measured in feet ( $\mathrm{ft}$ ) above the National Geodetic Vertical Datum of 1929 (NGVD 29).

Year

\section{Upland Terrace Aquifer}

Terrace deposits outcrop in interstream areas, primarily in the northeastern, central, and southeastern parts of Bossier Parish. About 45 percent of the surface area of the parish is underlain by terrace deposits, which consist of clay, silt, and fine sand grading to coarse sand and gravel at the bottom. Terrace deposits in the parish range in thickness from about 90 to $120 \mathrm{ft}$.

The upland terrace aquifer comprises water-bearing sands and gravels within the terrace deposits. In Bossier Parish, the upland terrace aquifer is generally overlain and confined by $50 \mathrm{ft}$ of clay and silt deposits, but it outcrops in some areas where the clay and silt are missing. Recharge to the aquifer is from precipitation in areas where it outcrops and from underlying deposits. Water in the upland terrace aquifer may be under water-table or artesian conditions, depending upon the presence of an overlying confining bed. Water in the upland terrace aquifer generally moves towards stream valleys. Water levels in the aquifer fluctuate about 0.5 to $2 \mathrm{ft}$ seasonally.

State well-registration records listed 154 active water wells screened in the upland terrace aquifer in Bossier Parish in 2009, including 121 domestic, 16 public-supply, 9 industrial, and 8 irrigation wells. Depths of these wells ranged from 18 to $136 \mathrm{ft}$ below land surface, with a median depth of $85 \mathrm{ft}$. Yields from wells screened in the upland terrace aquifer in Bossier Parish have reportedly ranged from 4 to $1,200 \mathrm{gal} / \mathrm{min}$. In 2005, withdrawals from the upland terrace aquifer in Bossier Parish totaled about 0.99 Mgal/d (table 1) and included about $0.65 \mathrm{Mgal} / \mathrm{d}$ for public-supply use, $0.21 \mathrm{Mgal} / \mathrm{d}$ for industry, $0.07 \mathrm{Mgal} / \mathrm{d}$ for rural-domestic use, $0.01 \mathrm{Mgal} / \mathrm{d}$ for livestock, $0.02 \mathrm{Mgal} / \mathrm{d}$ for rice irrigation, and $0.03 \mathrm{Mgal} / \mathrm{d}$ for general irrigation. 
A statistical summary of selected water-quality characteristics for freshwater samples collected from 37 wells screened in the upland terrace aquifer is provided in table 3. Freshwater from the aquifer ranges in hardness from soft (less than $60 \mathrm{mg} / \mathrm{L}$ as calcium carbonate) to very hard (greater than $180 \mathrm{mg} / \mathrm{L}$ as calcium carbonate) and generally does not exceed the U.S. Environmental Protection Agency's Secondary Maximum Contaminant Levels (SMCLs) ${ }^{2}$ for drinking water for color, $\mathrm{pH}$, iron, and dissolved solids. The median concentration $(140 \mu \mathrm{g} / \mathrm{L})$ of manganese in 13 samples exceeds the SMCL for drinking water of $50 \mu \mathrm{g} / \mathrm{L}$. Locally, iron concentrations can exceed the SMCL of $300 \mu \mathrm{g} / \mathrm{L}$.

\section{Sparta Aquifer}

The Sparta aquifer is generally present in the northeastern one-third of Bossier Parish. The aquifer consists of thick beds of sand that occur chiefly in the upper and basal parts of the aquifer, with clays mostly in the middle. The Sparta aquifer

\footnotetext{
${ }^{2}$ The SMCLs are nonenforceable Federal guidelines regarding cosmetic effects (such as tooth or skin discoloration) or aesthetic effects (such as taste, odor, or color) of drinking water. At high concentrations or values, health implications as well as aesthetic degradation might exist. SMCLs were established as guidelines for the States by the U.S. Environmental Protection Agency (1992).
}

outcrops in an irregular area southwest of the town of Plain Dealing and in smaller areas to the south-southeast. In Bossier Parish, the Sparta aquifer dips and thickens to the northeast; the base of the aquifer generally ranges from $50 \mathrm{ft}$ or more above NGVD 29 to $150 \mathrm{ft}$ below NGVD 29. The thickness of the Sparta aquifer ranges from a few feet to $300 \mathrm{ft}$. Recharge to the aquifer is provided by precipitation in sandy outcrop areas and by leakage from other aquifers in areas where it is overlain and confined by clays of the Cook Mountain confining unit.

State well-registration records listed 199 active water wells screened in the Sparta aquifer in Bossier Parish in 2009, including 172 domestic, 13 public-supply, 10 industrial, and 4 irrigation wells. Depths of these wells ranged from 42 to $360 \mathrm{ft}$ below land surface, with a median depth of $130 \mathrm{ft}$. Yields from wells screened in the Sparta aquifer in Bossier Parish have reportedly ranged from 5 to $450 \mathrm{gal} / \mathrm{min}$. In 2005, withdrawals from the Sparta aquifer in Bossier Parish totaled about $0.19 \mathrm{Mgal} / \mathrm{d}$ (table 1) and included about $0.07 \mathrm{Mgal} / \mathrm{d}$ for public-supply use, $0.10 \mathrm{Mgal} / \mathrm{d}$ for ruraldomestic use, $0.01 \mathrm{Mgal} / \mathrm{d}$ for rice irrigation, and $0.01 \mathrm{Mgal} / \mathrm{d}$ for general irrigation. Water from the Sparta aquifer in Bossier Parish is generally soft and does not exceed SMCLs for color, $\mathrm{pH}$, and dissolved solids; however, iron concentrations in some areas exceed the SMCL of $300 \mu \mathrm{g} / \mathrm{L}$.

Table 3. Summary of selected water-quality characteristics of freshwater in the upland terrace and Carrizo-Wilcox aquifers in Bossier Parish, Louisiana.

[Values are in milligrams per liter, except as noted. ${ }^{\circ} \mathrm{C}$, degrees Celsius; PCU, platinum cobalt units; $\mu \mathrm{S} / \mathrm{cm}$, microsiemens per centimeter; $\mathrm{SU}$, standard units; $\mathrm{CaCO}_{3}$, calcium carbonate; $\mu \mathrm{g} / \mathrm{L}$, micrograms per liter; NA, not applicable; SMCL, Secondary Maximum Contaminant Level established by the U.S Environmental Protection Agency (2011)]

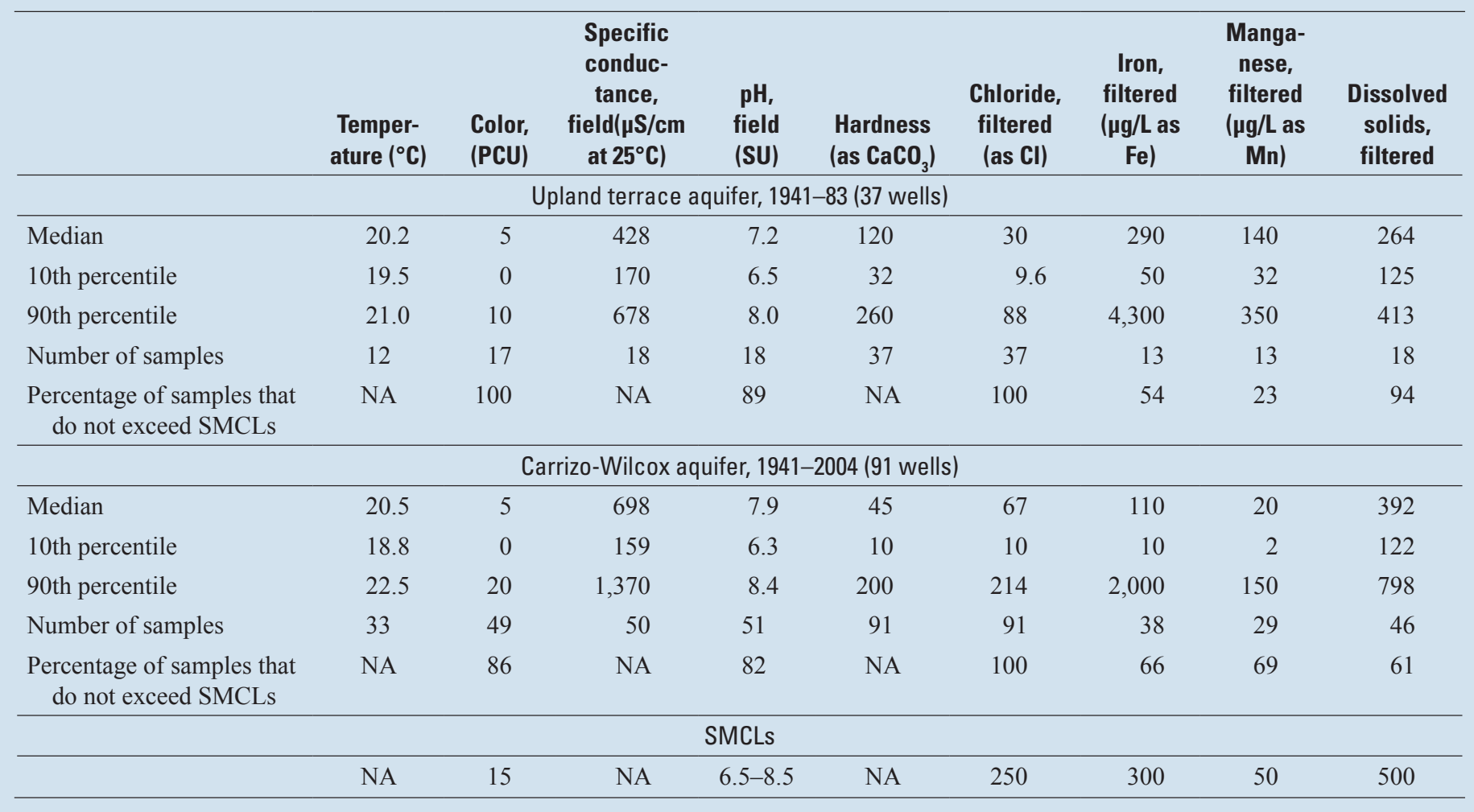




\section{Carrizo-Wilcox Aquifer}

The Carrizo-Wilcox aquifer consists of the Carrizo Sand and sand beds within the undifferentiated Wilcox Group, which are hydraulically connected and regionally act as a single unit. The Carrizo-Wilcox aquifer consists of clay interbedded with very fine to medium sand and is present throughout Bossier Parish. Individual sands of the Carrizo-Wilcox aquifer range in thickness from less than 10 to about $150 \mathrm{ft}$. In Bossier Parish, the Carrizo-Wilcox aquifer dips and thickens to the northeast, with the base of the aquifer ranging from about $0 \mathrm{ft}$ below NGVD 29 in the southern end of the parish to about $900 \mathrm{ft}$ below NGVD 29 in the northeastern corner of the parish. The aquifer is underlain by the clayey Midway confining unit (fig. 3). Freshwater can be found in the aquifer throughout Bossier Parish except in the northeastern area and from the town of Elm Grove southward. Brackish water occurs locally in shallow basal sands of the aquifer.

In the central and southern part of the parish, sands in the Carrizo-Wilcox aquifer outcrop or subcrop and receive recharge from precipitation. Locally, the aquifer discharges to streams and lakes. Groundwater movement in the northern third of the parish is generally westward toward the Red River Valley, which is a major discharge area. The direction of groundwater movement in the southern two-thirds of the parish, while generally westward, is affected by local water withdrawals. Groundwater-level data from 1991 indicate that withdrawals from the Carrizo-Wilcox aquifer near the town of Doyline in southwestern Webster Parish have formed a cone of depression in the water-level surface, causing water in the aquifer in east-central Bossier Parish to move towards Doyline. Water withdrawals near Wallace Lake in southeastern Caddo Parish have also formed a cone of depression, causing water in the aquifer in southwestern Bossier Parish to move towards Wallace Lake.

State well-registration records listed 2,075 active water wells screened in the Carrizo-Wilcox aquifer in Bossier Parish in 2009, including 1,948 domestic, 86 public-supply, 23 irrigation, and 18 industrial wells. Depths of these wells ranged from 33 to $710 \mathrm{ft}$ below land surface, with a median depth of $200 \mathrm{ft}$. Yields from wells screened in the CarrizoWilcox aquifer in Bossier Parish have reportedly ranged from 2 to $400 \mathrm{gal} / \mathrm{min}$. In 2005, withdrawals from the aquifer in Bossier Parish totaled about $2.45 \mathrm{Mgal} / \mathrm{d}$ (table 1) and included about $1.01 \mathrm{Mgal} / \mathrm{d}$ for public-supply use, $0.21 \mathrm{Mgal} / \mathrm{d}$ for industry, $1.09 \mathrm{Mgal} / \mathrm{d}$ for rural-domestic use, $0.02 \mathrm{Mgal} / \mathrm{d}$ for livestock, $0.05 \mathrm{Mgal} / \mathrm{d}$ for rice irrigation, and $0.08 \mathrm{Mgal} / \mathrm{d}$ for general irrigation.

A statistical summary of selected water-quality characteristics for freshwater samples collected from 91 wells screened in the Carrizo-Wilcox aquifer is provided in table 3. Based on median values of constituents listed in table 3 , freshwater from the Carrizo-Wilcox aquifer is generally soft (less than $60 \mathrm{mg} / \mathrm{L}$ as calcium carbonate) and does not exceed SMCLs for drinking water for color, $\mathrm{pH}$, iron, manganese, and dissolved solids; however, water from the Carrizo-Wilcox aquifer can locally exceed SMCLs for iron, manganese, and dissolved-solids.

\section{Surface-Water Resources}

In 2005, about $11.7 \mathrm{Mgal} / \mathrm{d}$ of surface water were withdrawn in Bossier Parish for public supply (Bossier City), industry, livestock, and general irrigation (table 2). The Red River is the primary source of fresh surface water in Bossier Parish. In 2005, the Bossier City Water System withdrew about $10.7 \mathrm{Mgal} / \mathrm{d}$ from the Red River for public-supply purposes. Other surface-water resources in the parish include Lake Bistineau, Cypress Bayou Reservoir, and Bodcau Bayou. Bodcau Bayou forms the northeastern parish line before draining southwest through central Bossier Parish. The average discharge of the bayou was 598 cubic feet per second $\left(\mathrm{ft}^{3} / \mathrm{s}\right)$ during 1939-92 at a site near Sarepta, La. (station number 07349500; U.S. Geological Survey, 2008). Many streams draining the upland areas of the parish are not dependable sources of supply because they do not have well-sustained flows during dry seasons.

The average discharge of the Red River was $19,500 \mathrm{ft}^{3} / \mathrm{s}$ during 1998-2008 at a site about 4.5 mi upstream from Bossier Parish at Spring Bank, Arkansas (station number 07344370; U.S. Geological Survey, 2008). The highest mean daily discharge of the Red River during this 10-year period was $138,000 \mathrm{ft}^{3} / \mathrm{s}$ on March 14, 2001, and the lowest was $1,100 \mathrm{ft}^{3} / \mathrm{s}$ on October 11,2006 . Water samples analyzed during 1995-2009 indicate that water in the Red River at Coushatta, La., located downstream from Bossier Parish in Red River Parish, is generally hard (121-180 mg/L as $\left.\mathrm{CaCO}_{3}\right)$. Based on median values, the $\mathrm{pH}$ and concentrations of chloride, sulfate, and iron generally did not exceed the SMCLs (table 4).

Lake Bistineau is a 26.9- $\mathrm{mi}^{2}(17,200$-acre) reservoir located in southeast Bossier, southwest Webster, and northwest Bienville Parishes. The reservoir has a volume of 120,000 acre- $\mathrm{ft}$, an average depth of $7 \mathrm{ft}$, and a maximum depth of $25 \mathrm{ft}$. Bayou Dorcheat is the primary tributary. Water samples collected at the southern end of the reservoir near the spillway (dam) during 1943-70 indicate that the water is soft. The $\mathrm{pH}$ of the water is generally slightly below the SMCL range of 6.5 to 8.5; concentrations of chloride and sulfate did not exceed the SMCLs (table 4).

The Cypress Bayou Reservoir, located about 10 mi north of Bossier City, was completed in 1975. The reservoir has a drainage area of $155 \mathrm{mi}^{2}$ and receives inflow from Cypress Bayou, Little Caney Bayou, and White Oak Bayou. The reservoir dam has a $250-\mathrm{ft}$ concrete spillway with a crest elevation of about $180 \mathrm{ft}$ above NGVD 29. When the elevation of the water surface in the reservoir is near the crest elevation, the surface area of the reservoir is about 3,400 acres, maximum depth is about $20 \mathrm{ft}$, average depth is about $6.7 \mathrm{ft}$, and the water volume is about 22,700 acre-ft. The reservoir is maintained and operated by the Cypress Black Bayou Recreation and Water Conservation District and is used for flood control, conservation, and recreation. 
Table 4. Summary of selected water-quality characteristics for the Red River at Coushatta, Louisiana (in Red River Parish), and Lake Bistineau (near Ringgold, La.).

[Values are in milligrams per liter, except as noted. ${ }^{\circ} \mathrm{C}$, degrees Celsius; $\mu \mathrm{S} / \mathrm{cm}$, microsiemens per centimeter; $\mathrm{SU}$, standard units; $\mu \mathrm{g} / \mathrm{L}$, micrograms per liter; $\mathrm{CaCO}_{3}$, calcium carbonate; <, less than; NA, not applicable; - , no data; SMCL, Secondary Maximum Contaminant Level established by the U.S. Environmental Protection Agency (2011)]

\begin{tabular}{|c|c|c|c|c|c|c|c|c|c|c|}
\hline & $\begin{array}{c}\text { Specific } \\
\text { conductance, } \\
\text { field } \\
(\mu \mathrm{S} / \mathrm{cm} \\
\left.\text { at } 25^{\circ} \mathrm{C}\right)\end{array}$ & $\begin{array}{l}\text { Oxygen, } \\
\text { dis- } \\
\text { solved }\end{array}$ & $\begin{array}{l}\text { pH, } \\
\text { field } \\
\text { (SU) }\end{array}$ & $\begin{array}{l}\text { Hard- } \\
\text { ness } \\
\text { (as } \\
\mathrm{CaCO}_{3} \text { ) }\end{array}$ & $\begin{array}{c}\text { Calcium, } \\
\text { filtered } \\
\text { (as Ca) }\end{array}$ & $\begin{array}{l}\text { Mag- } \\
\text { nesium, } \\
\text { filtered } \\
\text { (as Mg) }\end{array}$ & $\begin{array}{l}\text { Sodium, } \\
\text { filtered } \\
\text { (as Na) }\end{array}$ & $\begin{array}{c}\text { Chloride, } \\
\text { filtered } \\
\text { (as CI) }\end{array}$ & $\begin{array}{l}\text { Sulfate, } \\
\text { filtered } \\
\text { (as } \mathrm{SO}_{4} \text { ) }\end{array}$ & $\begin{array}{c}\text { Iron, } \\
\text { fil- } \\
\text { tered, } \\
\text { ( } \mu \mathrm{g} / \mathrm{L} \\
\text { as Fe) }\end{array}$ \\
\hline \multicolumn{11}{|c|}{ Red River at Coushatta, 1995-20091 } \\
\hline Median & 504 & 8.1 & 7.8 & 140 & 37 & 10 & 49 & 65 & 64 & 20 \\
\hline 90th percentile & 1,200 & 11.8 & 8.2 & 290 & 73 & 23 & 130 & 190 & 160 & 90 \\
\hline Number of samples & 170 & 156 & 172 & 167 & 167 & 169 & 168 & 170 & 170 & 66 \\
\hline $\begin{array}{l}\text { Percentage of samples that } \\
\text { do not exceed SMCLs }\end{array}$ & NA & NA & 93 & NA & NA & NA & NA & 99 & 100 & 100 \\
\hline \multicolumn{11}{|c|}{ Lake Bistineau near Ringgold, $1943-70^{2}$} \\
\hline Number of samples & 12 & - & 19 & 13 & 12 & 12 & 12 & 20 & 19 & - \\
\hline $\begin{array}{l}\text { Percentage of samples that } \\
\text { do not exceed SMCLs }\end{array}$ & NA & - & 32 & NA & NA & NA & NA & 100 & 100 & - \\
\hline \multicolumn{11}{|c|}{ SMCLs } \\
\hline & NA & NA & $6.5-8.5$ & NA & NA & NA & NA & 250 & 250 & 300 \\
\hline
\end{tabular}

${ }^{1}$ Station number 07350500 (U.S. Geological Survey, 2011; specific data at http://nwis.waterdata.usgs.gov/la/nwis/qwdata/?site_no=07350500).

${ }^{2}$ Station number 07349250 (U.S. Geological Survey, 2011; specific data at http://nwis.waterdata.usgs.gov/la/nwis/qwdata/?site_no=07349250).

\section{Selected References}

Page, L.V., and May, H.G., 1964, Water Resources of Bossier and Caddo Parishes, Louisiana: Department of Conservation, Louisiana Geological Survey, and Louisiana Department of Public Works Water Resources Bulletin no. 5, 105 p.

Sargent, B.P., 2007, Water use in Louisiana, 2005: Louisiana Department of Transportation and Development Water Resources Special Report no. 16, $133 \mathrm{p}$.

Smoot, C.W., 1988, Louisiana hydrologic atlas map no. 3: Altitude of the base of freshwater in Louisiana: U.S. Geological Survey WaterResources Investigations Report 86-4314, 1 sheet.

Snider, J.L., 1983, Ground-water resources of the Fillmore-HaughtonRed Chute area, Bossier and Webster Parishes, Louisiana: Louisiana Department of Transportation and Development, Office of Public Works Water Resources Technical Report no. 32, 21 p.

U.S. Environmental Protection Agency, 1992, Secondary Drinking Water Regulations-guidance for nuisance chemicals: U.S. Environmental Protection Agency publication EPA 810/K-92-001, 4 p., accessed September 28, 2011, at http://water.epa.gov/drink/ contaminants/secondarystandards.cfm.

U.S. Environmental Protection Agency, 2011, 2011 Edition of the drinking water standards and health advisories: Washington, D.C., U.S. Environmental Protection Agency, Office of Water, EPA 820-R11-002, 12 p., accessed September 2, 2011, at http://water.epa.gov/ action/advisories/drinking/upload/dwstandards2011.pdf.

U.S. Geological Survey, 2008, Water-resources data for the United States Water Year 2008: U.S. Geological Survey Water-Data Report WDR-US-2008, accessed November 6, 2009, at http://wdr.water. usgs.gov/.
U.S. Geological Survey, 2010, Ground-water levels for Louisiana [data for USGS323103093414201 Bo-377]: National Water Information System Web Interface, accessed November 5, 2009, at http://nwis. waterdata.usgs.gov/la/nwis/gwlevel/?site_no $=323103093414201$.

U.S. Geological Survey, 2011, Water quality samples for Louisiana: National Water Information System Web Interface, accessed February 16, 2010, at http://nwis.waterdata.usgs.gov/la/nwis/ qwdata/.

Whitfield, M.S., Jr., 1980, Chemical character of water in the Red River alluvial aquifer, Louisiana: U.S. Geological Survey WaterResources Investigations Open-File Report 80-1018, 95 p.

\section{By Lawrence B. Prakken and Jason M. Griffith}

\section{For additional information, contact:}

Director, USGS Louisiana Water Science Center 3535 S. Sherwood Forest Blvd., Suite 120

Baton Rouge, LA 70816

E-mail: dc la@usgs.gov

Fax: (225) 298-5490

Telephone: (225) 298-5481

Home Page: http://la.water.usgs.gov

This fact sheet was published by the U.S. Geological Survey, in cooperation with the Louisiana Department of Transportation and Development (DOTD). Thanks are given to Zahir "Bo" Bolourchi, Director, Water Resources Programs, Louisiana Department of Transportation and Development, who contributed to the content and design of the fact sheet. 